\title{
NOTES ON NEARCTIC NEUROPTERA
}

\section{By F. M. CARPENTER}

Since the publication of my revision of the Nearctic Hemerobiidæ and related Neuroptera, ${ }^{1}$ several collections of these insects have been sent to me for identification. Notes on the most interesting and unusual species are included here. I am indebted to the entomologists mentioned below for the opportunity of examining this additional material.

\section{FAMILy HeMEROBIID $\not E$}

Kimminsia involuta Carp.

In the Cornell University collection there are four specimens ( $\hat{o} q$ ) of this species collected in North Carolina ("N.C.") by F. Sherman, Jr. Involuta has previously been known only from western Canada, Idaho, Wyoming and Colorado. In all probability these specimens were found in the mountainous (western) part of $\mathrm{N}$. Carolina, the insect fauna of which has several other species and genera in common with that of the north-western states.

\section{Megalomus mostus Banks}

Several specimens ( 0 \% ) were collected in the Black Hills, South Dakota (July 20, 1939) by D. J. and J. N. Knull (Ohio State University collection). The most eastern record of mostus has previously been at Laramie, Wyoming.

Sympherobius angustus (Banks)

One female was collected in the Chirichua Mts., Arizona (July 15, 1939, D. J. and J. N. Knull); it is the first record of angustus in that state.

Sympherobius arizonicus Banks

The $q$ type has previously been the only specimen of this insect known to me. In the Ohio State University collection there are three additional specimens from the Santa Rita Mts.,

${ }^{1}$ Proc. Amer. Acad. Arts and Sciences, 74:193-278, 1940. 
Arizona (June 8 and 24, D. J. and J. N. Knull). Unfortunately, all of these are females, so that the male genital structure is still unknown.

Sympherobius occidentalis (Fitch)

One specimen of this rare insect has been collected in Indiana Dunes State Park, Indiana (July 27, 1940) by R. L. Wenzel (Field Mus. collection); this is the first record in that state.

\section{FAMILY SisYRID $A$ E}

Climacia areolaris (Hagen)

A number of specimens were collected at the Deschutes River, near Richmond, Oregon (July 28 and 31, 1939, Shuh and Gray); and others have more recently been collected near Tower, Minnesota (University of Minnesota collection). These records greatly extend the range of areolaris, which has not previously been reported west of Michigan in the north or New Mexico in the south. It will probably turn up locally across northern United States.

\section{FAMILY BeROTHIDAE}

Lomamyia banksi Carp.

A female collected at Buffalo, Texas (June 29, 1941, D. J. and J. N. Knull) is the first record in that state.

Lomamyia longicollis (Walker)

A male of this little-known insect is contained in the Uni-

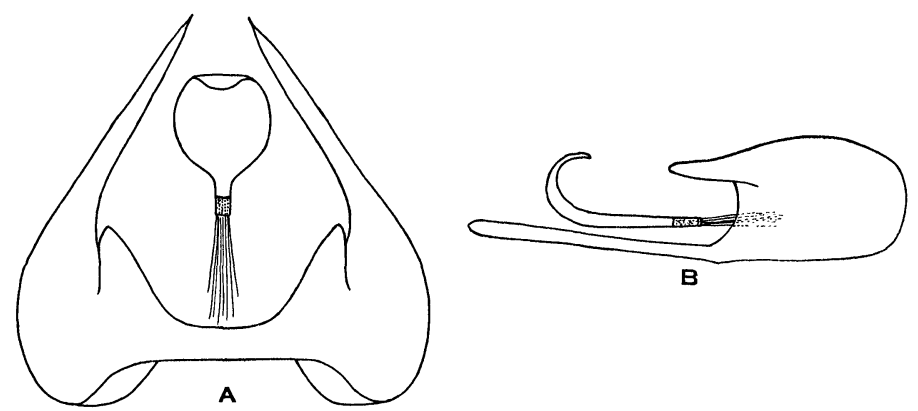

FIG. 1. Lomamyia longicollis (Walker) $\hat{o}$, tenth abdominal tergite and ædeagus. A, dorsal view; $\mathrm{B}$, lateral view. 
versity of Kansas collection; it was found at Iuka, Mississippi (July 14, 1930) by R. H. Beamer (University of Kansas collection), and is the only male known to me in addition to the type in the British Museum. Since the male genitalia of this species have not previously been described, I include here (Fig. 1) a drawing of the 10th abdominal tergite and ædeagus. The tergite is similar to that of tenuis Carp., but lacks the anterior and posterior dorsal lobes. The ædeagus also resembles that of tenuis. 

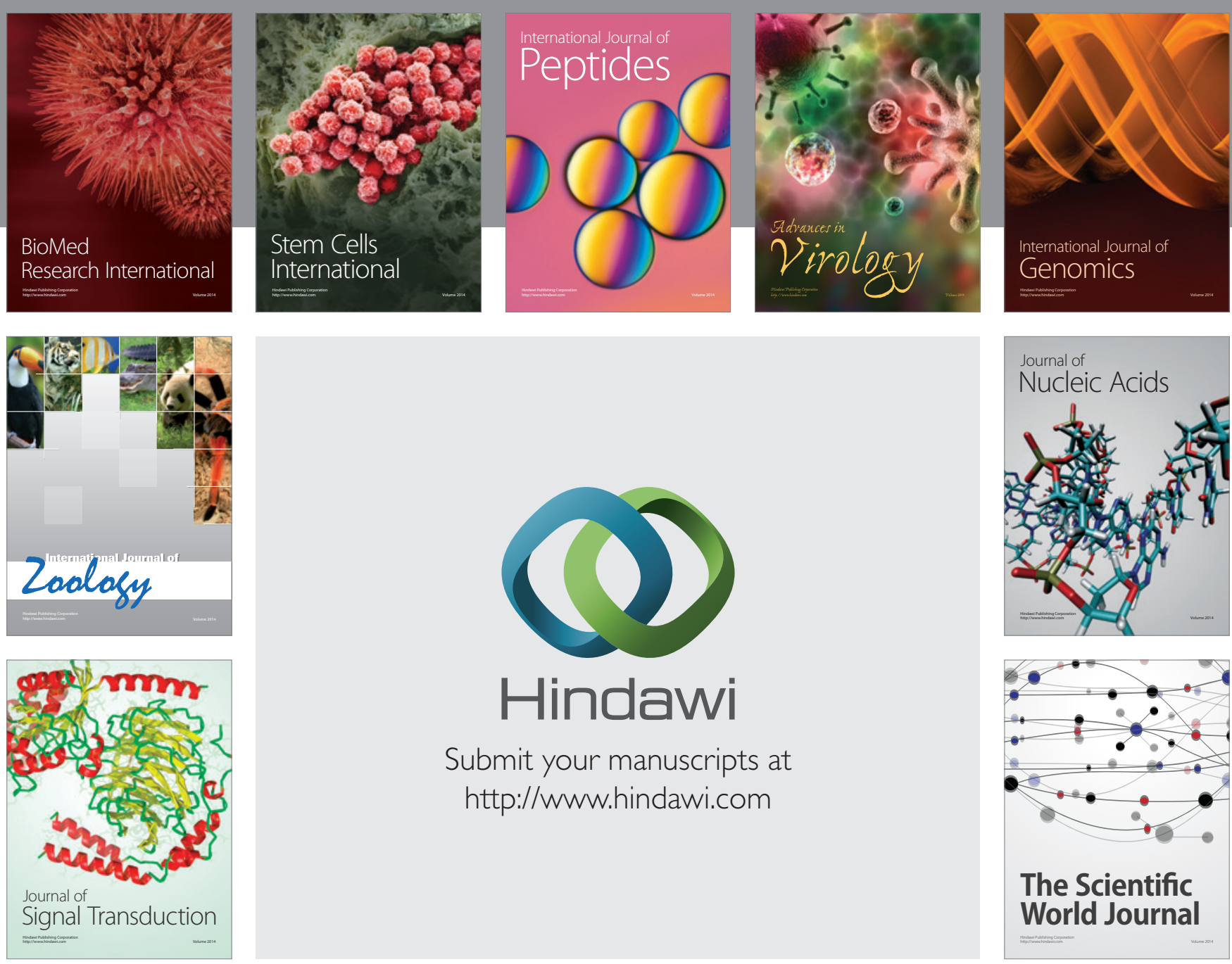

Submit your manuscripts at

http://www.hindawi.com
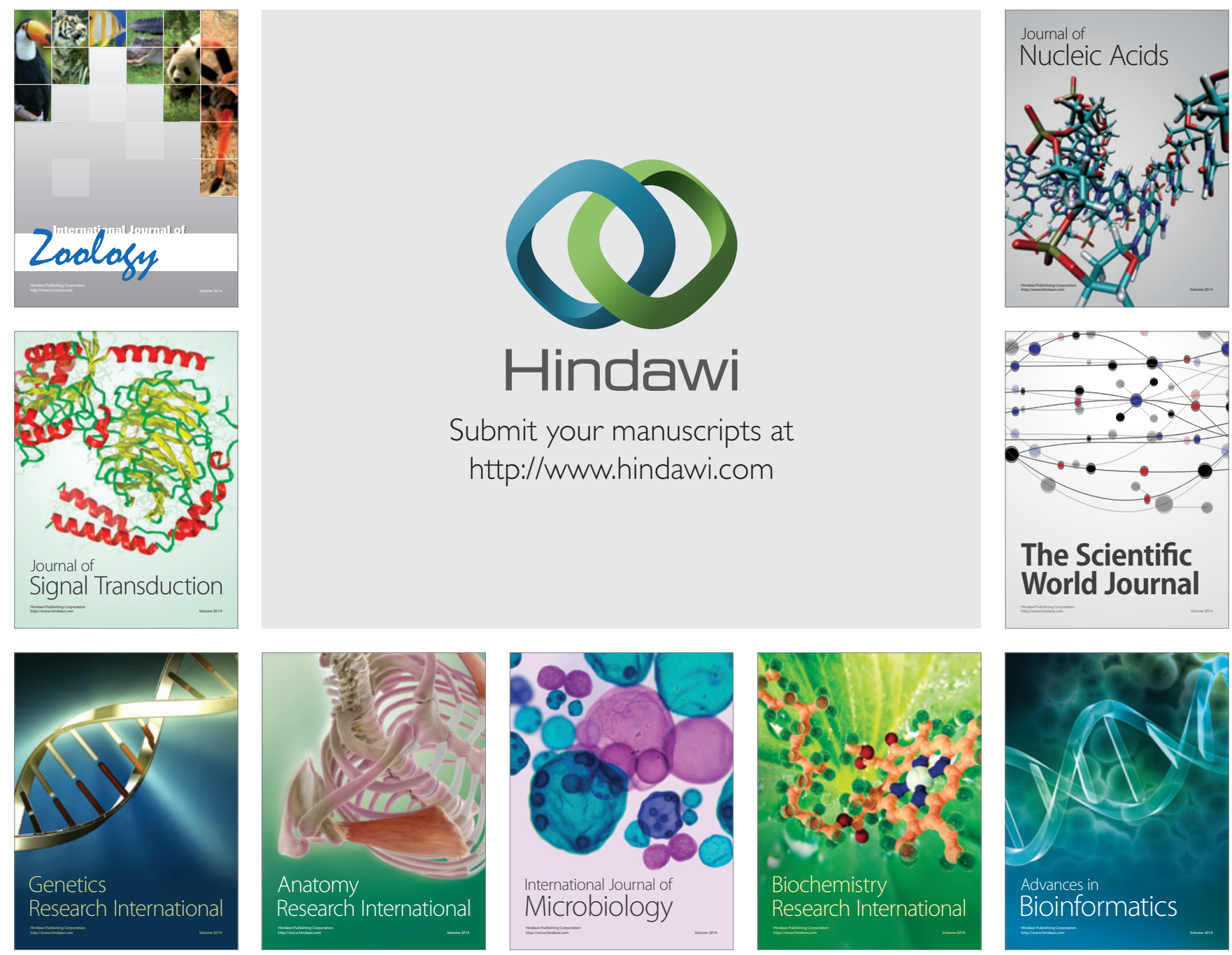

The Scientific World Journal
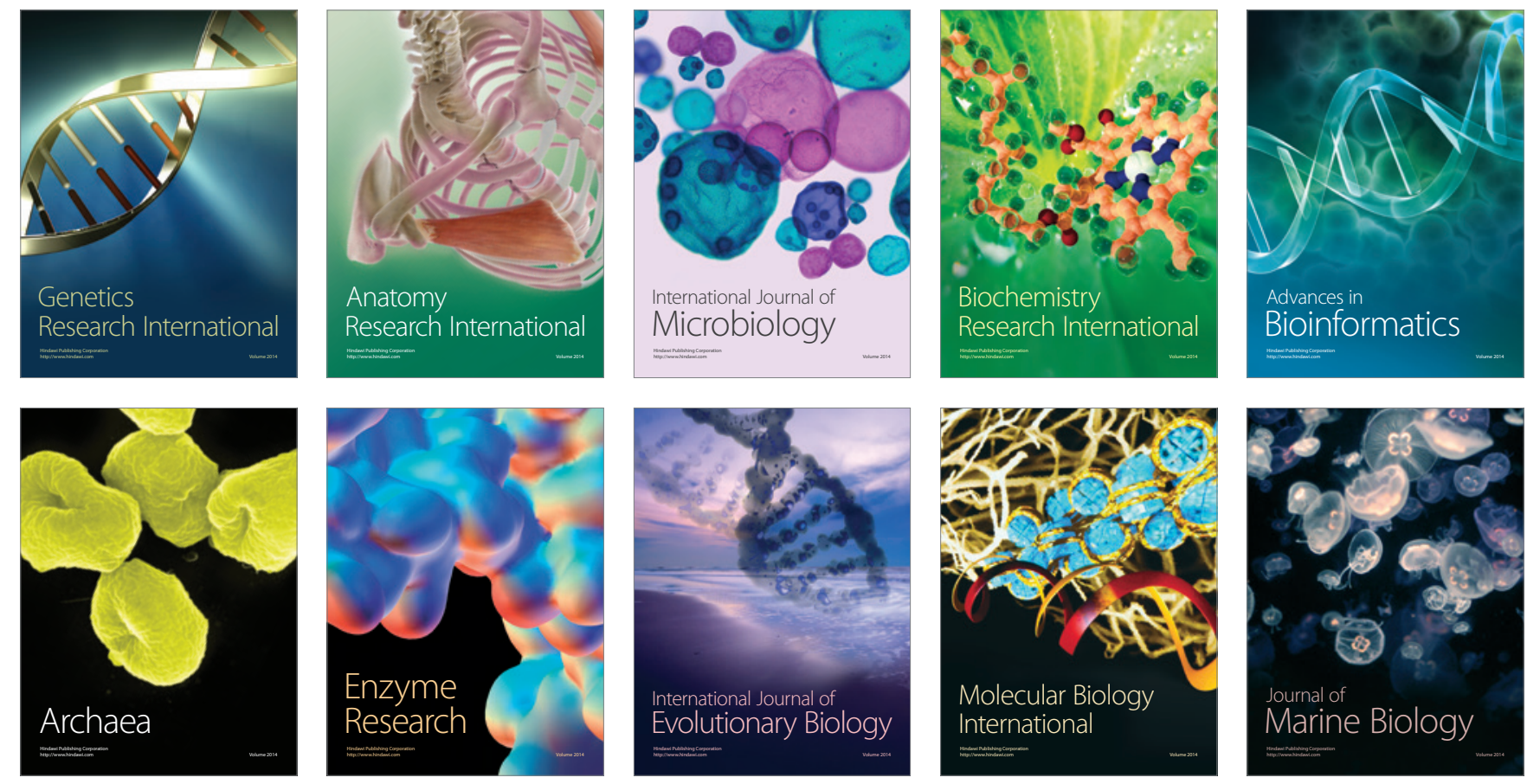